\title{
Memórias de uma "Cidade Olímpica": análise dos filmes Rio eu te amo e Olympia
}

\author{
Memories of the "Olympic City": analysis of the films Rio I love you and \\ Olympia
}

Recuerdos de la "Ciudad Olímpica": análisis de las películas de "Rio eu te amo" y "Olympia"

Igor Lacerda ${ }^{1}$

\begin{abstract}
Resumo
Este trabalho tem o objetivo de analisar as representações da cidade do Rio de Janeiro em dois filmes produzidos no período dos megaeventos: o "Rio, eu te amo" (2014) e o "Olympia" (2016). A análise de narrativas foi escolhida como a metodologia deste trabalho, e serão utilizadas as perspectivas de Paul Ricoeur (1994). O autor pode contribuir para a investigação e a problematização dos processos de produção das narrativas fílmicas, auxiliando no entendimento da formação de sentido. E para compreender as memórias produzidas e silenciadas pelos dois filmes, recorreu-se a autores como Pollak (1989) e Mendonça (2018). Entendemos que o "Rio, eu te amo" pode ter sido utilizado para fazer o branding da marca-Rio, trazendo as "memórias oficiais". O "Olympia", por outro lado, levando em consideração seu planejamento, produção e divulgação, deve trazer à memória temas que a gestão da marca teve a intenção de silenciar. Ou seja, o "Olympia", percebido como "militante" ou "ativista", traz as "memórias subterrâneas".
\end{abstract}

Palavras-chave: memórias oficiais; memórias subterrâneas; megaeventos; branding urbano; cinema brasileiro.

\begin{abstract}
This article aims to analyze the representations of the city of Rio de Janeiro in two films produced in the period of mega events: "Rio, I love you" (2014) and "Olympia" (2016). The analysis of narratives was chosen as the methodology, and the perspectives of Paul Ricoeur (1994) was used. The author can contribute to the investigation and problematization of the processes of production of the film narratives, helping in the understanding of a process of formation of meaning. And to understand the memories produced and silenced by the two films, authors like Pollak (1989) and Mendonça (2018) were used. We understand that "Rio, I love you" may have been used to make the Rio de Janeiro's brand management, bringing the "official memories." "Olympia", on the other hand, taking into consideration its planning, production and dissemination, should bring to mind themes that brand management intended to silence. So "Olympia", perceived as "militant" or "activist", brings the "underground memories".
\end{abstract}

Key-words: official memories; underground memories; mega events; urban branding; brazilian cinema.

\section{Resumen}

Este artículo pretende analizar las representaciones de la ciudad de Río de Janeiro en dos películas producidas en el período de mega eventos: "Río, me encanta" (2014) y "Olympia” (2016). El análisis de las narrativas se eligió como la metodología y se utilizaron las perspectivas de Paul Ricoeur (1994). El autor puede contribuir a la investigación y problematización de los procesos de producción de las narrativas cinematográficas, ayudando en

\footnotetext{
${ }^{1}$ Mestrando em Comunicação pela Universidade do Estado do Rio de Janeiro (Bolsista Capes), pesquisador no Laboratório de Comunicação, Cidade e Consumo (Lacon - UERJ) e graduado em Comunicação Social. E-mail: igorlacerdasa@gmail.com
} 
la comprensión de un proceso de formación de significado. Y para comprender los recuerdos producidos y silenciados por las dos películas, se utilizaron autores como Pollak (1989) y Mendonça (2018). Entendemos que "Rio: me encanta" que haya sido usado para hacer la gestión de marca de Rio de Janeiro, trayendo los "recuerdos oficiales". "Olympia", por otro lado, teniendo en cuenta su planificación, producción y difusión, debe recordar los temas que la gestión de la marca pretende silenciar. Así que Olimpia, percibida como "militante" o "activista", trae los "recuerdos subterráneos".

Palabras clave: memorias oficiales; recuerdos subterráneos; mega eventos; branding urbano; cine brasileño.

\section{Introdução}

Cheguei ao nome da cidade

Não à cidade mesma, espessa

Rio que não é rio: imagens

Essa cidade me atravessa

$\hat{O}$ ! $\hat{E}$ boi! $\hat{E}$ bus!

Será que tudo me interessa?

Cada coisa é demais e tantas

Quais eram as minhas esperanças?

O que é ameaça e o que é promessa?

Ruas voando sobre ruas

Letras demais, tudo mentira

O Redentor, que horror! Que lindo!

Meninos maus, mulheres nuas

Ô! $\hat{E}$ boi! $\hat{E}$ bus!

A gente chega sem chegar

Não há meada, é só o fio

Será que pra meu próprio rio

Este rio é mais mar que o mar?

(Maria Bethânia - O nome da cidade)

Começo este trabalho com a música "O nome da cidade" de Caetano Veloso, interpretada por sua irmã Maria Bethânia. Ouço como se fosse um lamento, a angústia de um viajante que veio de longe trazendo poucos pertences e muitas lembranças. Há desilusão nessa letra, como se o Rio idealizado, encantado, morresse logo na chegada: "não há cidade mesma, espessa/ Rio que não é rio, imagens". Desencantado, é atravessado por essa "cidade espessa" e por todos os seus encantos, conflitos e misérias. Ficou atordoado, revendo os planos que o levaram até ali: "Será que tudo me interessa? / Cada coisa é demais e tantas/ Quais eram as minhas esperanças?/ O que é ameaça e o que é promessa?”. Imagino que os prédios em desalinho, os ruídos dos carros, as pessoas apressadas e o excesso de comunicações tenham causado um estranhamento nesse estrangeiro: "Ruas voando sobre ruas/ Letras demais, tudo mentindo/ O Redentor, que horror! Que lindo!”. Ele não sabe mais o que é certo e o que é errado. E no fim, percebe que o Rio não é tão amável e acolhedor assim, ele também pode causar medo: "A gente chega sem chegar/ Não há meada, é só o fio".

Os grandes meios de comunicação deram "o nome da cidade" nesses últimos anos: "global", “olímpica", "revitalizada". A visibilidade foi trazida principalmente por 
megaeventos como a Copa do Mundo de 2014 e os Jogos Olímpicos de 2016, além de grandes eventos sazonais como o Carnaval e o Réveillon de Copacabana. A mídia hegemônica destacou um "Rio que não é rio: imagem", alimentando as memórias sobre a metrópole e os seus habitantes: "não a cidade mesma, espessa”, mas repletas de belezas naturais, exuberante, inovadora, apta à receber investimentos e preparada para os desafios do futuro, sem "meninos maus, mulheres nuas", com cariocas receptivos, acolhedores e felizes com o futuro. "Será que pra meu próprio rio/ Este rio é mais mar que o mar?", é a dúvida que se alinha a este artigo.

O propósito deste estudo é identificar e analisar as memórias do Rio de Janeiro em filmes contemporâneos divulgados no período em que a cidade foi repaginada para os megaeventos: 2014 e 2016. Interessante investigar essa fase de remodelação do urbano através do cinema, pois esse meio pode ter servido de arena para o confronto das múltiplas narrativas sobre os eventos internacionais, como é o caso de Rio - eu te amo (2014) e "Olympia" (2016). Partimos da hipótese de que as memórias contidas no Rio - eu te amo foram enquadradas a fim de corresponder aos anseios do mercado, visando atrair investimentos e consumos. Por outro lado, o "Olympia" foi criado para confrontar as "memórias oficiais", apresentando aos telespectadores as "memórias subalternas" do Rio que não é só uma cidade bela, solar e fascinante, pelo contrário: é repleta de caos e contradições.

As mídias tradicionais e os movimentos sociais, ambos defendendo os seus interesses, acompanharam ações de remodelação do espaço urbano, vivendo as regalias e os males dessas intervenções. Além disso, esses atores fizeram alguns registros, interpretando as transformações ocorridas na então sede de megaeventos. Freitas (2013) diz que esses eventos seriam importantes, pois trariam visitantes que movimentariam o turismo, o comércio local e a hotelaria. Além disso, os capitais nacionais e estrangeiros seriam investidos na cidade a fim de aprimorar seus serviços de transporte, moradia, segurança, esporte e cultura. Todavia, Fortuna (2013) esclarece que eles afetaram negativamente a vida de pessoas que foram removidas de suas casas, tendo de conviver com obras, reformas no trânsito e redução do espaço público.

O "Rio, eu te amo" faz parte do Cities of Love - projeto que reúne cineastas com o propósito de produzir curtas sobre as metrópoles ou tendo-as como plano de fundo, ademais foram elaboradas também películas sobre Paris e Nova Iorque. É um filme composto por dez curtas, dirigidos por onze cineastas. Os brasileiros fizeram os seguintes curtas-metragens: "Dona fulana" (Andrucha Waddington), "Musa" (Fernando Meirelles), "Pas de deux" (Carlos Saldanha) e "Inútil paisagem" (José Padilha). Os estrangeiros fizeram: "O milagre" (Nadine Labaki), “O vampiro do Rio” (Im Sang Soo), “Texas” (Guillermo Arriaga), “Quando não há 
mais amor" (John Turturro), "Musa" (feito também pelo uruguaio César Charlone), "Acho que estou apaixonado" (Stephan Elliott) e "La fortuna" (Paolo Sorrentino).

Foi realizado pela Conspiração Filmes (produtora independente) em parceria com a Warner Bros Entertainment e patrocinado pela Prefeitura da Cidade do Rio de Janeiro. A Conspiração Filmes é uma empresa que atua desde 1991 nos seguintes segmentos: cinema, publicidade, televisão, branded content e vídeos para mídias digitais. Ela se destaca por associar conteúdos de cinema e televisão, mídias mais clássicas, à smartphones e internet, mídias mais novas. Ou seja, essa película foi pensada tanto para a web quanto para o cinema, por isso foram divulgadas imagens antes de seu lançamento com a intenção de criar expectativa no público. Aliás, os espectadores também foram convocados a participar, enviando suas “declarações de amor à cidade” em vídeos e fotografias.

Já o "Olympia”, foi dirigido por Rodrigo Mac Niven, é um filme que mistura ficção e documentário. Só pôde ser feito graças a um financiamento coletivo que contou com 535 patrocinadores e um total de $\mathrm{R} \$ 83.080$, já o orçamento final foi de $\mathrm{R} \$ 103.796,25$. Ele foi exibido pela primeira vez no dia da abertura dos Jogos Olímpicos (5 de agosto de 2016), não nos espaços ocupados pelos megaeventos, mas na Praça Marechal Floriano, na Cinelândia, região central da cidade.

A análise de narrativas foi escolhida como a metodologia deste trabalho, utilizando as perspectivas de Paul Ricoeur (1994). O autor pode contribuir para a investigação e problematização dos processos de produção das narrativas fílmicas, auxiliando no entendimento de um procedimento de formação de sentido. Para compreender as memórias produzidas e silenciadas pelos dois filmes, recorremos a autores como Pollak (1989) e Mendonça (2018).

\section{Análise de narrativas}

Para aprofundar as investigações sobre as memórias do Rio olímpico nos filmes "Rio, eu te amo" e "Olympia”, recorremos à tríplice mimesis de Ricoeur (1994). O objetivo é conceituar mimesis I, mimesis II e mimesis III a fim de articular aquilo que o autor chama de arco hermenêutico, ou seja, o processo interpretativo da tríplice mimesis.

Mimesis I é o mundo prefigurado, o que seria o alimento do roteirista ou do diretor na hora de pensar em um filme. É a forma que o narrador conhece o mundo social que o cerca, com todos os seus acordos, contradições e complexidades, e transfere esses conhecimentos pela narrativa. A mimesis I apresenta as seguintes dimensões: estruturais, simbólicas e 
temporais. A estrutural corresponde especificamente às formas de contar uma história, àquelas compartilhadas por uma determinada sociedade. São os códigos e as normas usadas na produção da narração, por exemplo. A dimensão simbólica diz respeito a crenças, valores e mitos utilizados pelo profissional de cinema para dar sentido à sua narrativa. $\mathrm{E}$ a dimensão temporal corresponde essencialmente às possibilidades da temporalidade portadora, são os tempos passado, presente e futuro contidos na narrativa.

A mimesis II é o que o autor compreende como tecer a intriga, um ato que acontece enquanto se narra. A tessitura da intriga, a mimesis II, media o mundo que precede a narrativa (o mundo prefigurado, mimesis I) e o mundo que vem depois da circulação dessa narrativa (o mundo refigurado, mimesis III). Então, o papel da mimesis II é ligar, por intermédio da produção do discurso em si, mimesis I à mimesis III. Ou seja, ao dirigir um filme, o diretor configura o universo, apresentando novos sentidos ou reforçando os antigos. Segundo o autor, essa mimesis tem a função de configuração, pois, através dela, o narrador produz lembranças e esquecimentos sobre o mundo preconfigurado, gerando outras concepções sobre ele.

Em mimesis III, o espectador é convidado a participar desta trama, podendo se tornar parte integrante dessa produção de sentidos. Mas ele não exerce essa função de forma passiva, pelo contrário: tem o papel de reconfiguração - são apropriações e reapropriações feitas por esse sujeito que tem suas próprias visões de mundo. Assim, ao assistir a um produto cinematográfico, o público tem a possibilidade de concordar com ele, reafirmando os sentidos ali descritos, ou discordar, vislumbrando novas perspectivas sobre o universo.

A tríplice mimesis pode passar a ideia de circularidade, mas Ricoeur (1994) explica que ela deve ser espiralada. No processo espiralado, mimesis III volta a mimesis I de forma reinventada e, assim, as significações são constantemente transformadas. Todavia, percebemos que as narrativas de "Rio, eu te amo" vão de mimesis I à mimesis III de forma cíclica, visando abafar o pensamento crítico ao fixar o público nos mesmos temas e perspectivas. "Olympia”, por outro lado, é uma narrativa mais flexível, pois apresenta um confronto de ideias de forma crítica e, como consequência, produz novas significações sobre a recepção dos megaeventos.

\section{Uma cidade, abundantes memórias}

O Rio de Janeiro, assim como outras cidades, recebeu os megaeventos internacionais e os utilizou como um suporte para remodelar o espaço urbano em um curto período transformações que serviram para qualificar sua marca em um competitivo mercado, onde 
outras metrópoles também estavam buscando investimentos, consumos e negócios. Com isso, os profissionais de marketing entraram em cena, aplicando as estratégias de branding $^{2}$ urbano a fim de fortalecer a imagem e a marca do Rio - nesse processo, a identidade e a suposta vocação da capital fluminense para hospedar grandes eventos foram os principais argumentos de venda (SÁNCHEZ, 2013).

\begin{abstract}
As cidades pulsam. Sensíveis, as cidades comunicam afetos, sentimentos e emoções que delas nascem. Também são palcos de conflitos, negociações e infinitos processos de comunicação. Elas são ambientes de consumo e para consumo. As cidades são, por excelência, campos de análise da comunicação por serem espaços permanentes de expressões de todas as ordens. São mídias, personagens, roteiros e cenários, além de centros produtores de cultura. Ao mesmo tempo, algumas autoridades públicas veem as cidades como mercadorias, obrigando-as a se submeterem a embalagens contemporâneas de produto ou a se comportarem como empresas (FREITAS, 2017, p. 50)
\end{abstract}

Jaguaribe (2011) esclarece que essa gestão da marca Rio (branding urbano) foi feita não só pelos governos estadual, municipal e federal, também por empresários, urbanistas e empresas de comunicação interessadas no projeto. Fortuna (2016) explica que a mídia, reproduzindo o discurso institucional dos governos, contribuiu com o branding ao ressaltar as memórias de uma cidade "global", "maravilhosa" e com "vocação para receber megaeventos", silenciando sistematicamente os processos de gentrificação ${ }^{3}$ e as violações aos direitos humanos. Entendemos, assim, que o city branding é um trabalho de enquadramento da memória, onde atributos entendidos como positivos são lembrados e os tidos como negativos são apagados. Segundo Pollak (1989), o enquadramento da memória é um processo complexo e conflituoso que envolve atores profissionais que enquadram as lembranças conforme os seus interesses.

O trabalho de enquadramento da memória se alimenta do material fornecido pela história. Esse material pode ser sem dúvida interpretado e combinado a um semnúmero de referências associadas [...] Esse trabalho de enquadramento da memória tem seus atores profissionalizados, profissionais da história, das diferentes organizações de que são membros, clubes e células de reflexão (POLLAK, 1989, p. 9-10)

\footnotetext{
2 De acordo com Gotardo (2016, p. 23), o branding é "um processo de construção de uma marca para torná-la visível e identificável (...) com o objetivo de facilitar a identificação de produtos, serviços e negócios e diferenciá-los dos concorrentes, o branding comunica principalmente benefícios e valores”. São estratégias adotadas a fim de agregar valor e significado a um produto ou serviço, fazendo uso de uma variedade de repertórios e memórias para maximizar lucros.

${ }^{3}$ De acordo com Mendonça (2016), a gentrificação é um fenômeno que decorre do processo de revitalização urbana, quando os espaços urbanos supostamente abandonados são "renovados", aumentando o custo de vida e, consequentemente, afastando os moradores antigos e conquistando novos grupos sociais e econômicos.
} 
Para Pollak (1989), podem existir confrontos entre as memórias oficiais - àquelas que selecionam e ordenam os acontecimentos, contendo estrategicamente (de acordo com os interesses vigentes) zonas de sombra, silêncios e esquecimentos - e as memórias subterrâneas - àquelas preservadas por grupos étnicos e políticos, por exemplo, que transmitem e conservam lembranças reprimidas ou ignoradas pelos idealizadores da memória oficial. Os grandes meios de comunicação, coligados às narrativas organizacionais dos governos, criaram memórias oficiais (como é o caso do "Rio, eu te amo") que entraram em embate com as memórias subterrâneas (como é a situação de "Olympia").

Em momentos de crise, as disputas em torno de uma determinada memória podem trazer à cena as memórias subterrâneas que estavam esquecidas ou silenciadas, como adverte o autor. Desta maneira, por mais que as narrativas governamentais e comunicacionais estivessem se esforçando para enquadrar as memórias do "Rio Olímpico", se empenhando em silenciar temas caros a alguns grupos na tentativa de levá-los ao esquecimento, essas pessoas possuíam fortes experiências com a cidade, impossíveis de serem apagadas ou domesticadas. E essas lembranças ganharam visibilidade nas ruas e nas redes num momento de crise desse projeto que se propunha a investir numa imagem de cidade global, apta a receber megaeventos, que trazia os encantos do Rio de Janeiro à memória e calava seus assombros.

O silêncio não leva ao esquecimento ou ao consenso, pelo contrário: Pollak explica que é a resistência necessária para que grupos insatisfeitos se oponham ao excesso de discursos oficiais. Para Mendonça (2018), a questão do silêncio não busca apenas o que não foi dito, afinal: o silêncio não fala, mas comunica e é significante. O silêncio não é a falta de palavras. Impor o silêncio não é calar, mas sim não dar visibilidade às demandas e às experiências do outro por terem a possibilidade de desmanchar os consensos. Com isso, falase sobre alguns assuntos para não dizer outros tantos - ou não permitir que digam - já que podem causar rupturas significativas numa relação de sentidos.

Pensar a questão do silêncio não é buscar apenas o que não se disse. O silêncio não fala, mas significa, cabe-nos a missão de entender para quais posições nos jogos de poder tais silenciamentos apontam. Em outras palavras, quem (ou que aspectos da complexidade das questões) está sendo silenciado quando apenas uma fonte (ou um "modelo" de interpretação do real) está sendo autorizada a falar e a emitir opiniões (MENDONÇA, 2018, p. 116)

Halbwachs (2003), ao formular o conceito de memória coletiva, destaca uma dimensão social da memória. Não nega a existência de memórias individuais, mas entende que elas são formadas sobretudo pelas memórias dos grupos. Assim, todas as lembranças, mesmo àquelas mais íntimas, como os pensamentos e os sentimentos, estão relacionadas com 
um conjunto de noções compartilhadas pelos outros: linguagens, lugares, ideias, assim como tudo que compõe a vida e os princípios dos grupos sociais. Para o autor, a memória seria responsável por garantir o funcionamento da vida social, pois, sem referências comuns, a sociedade não vigoraria. Ricoeur (2007) completa, explicando que o sujeito que lembra está imerso em uma rede de sentidos com a qual precisa dialogar, inclusive para transformá-la. Se os signos forem desconhecidos, mais difícil será seu processo de compreensão e transformação. Todavia, o autor lembra que os vínculos articulados pela memória podem ser espontâneos e efêmeros uma vez que é possível trocar de grupo, abandonar as antigas perspectivas e adquirir novas, ou até mesmo misturar a velha com a recém adquirida.

O Rio - eu te amo é um projeto realizado por onze cineastas diferentes, com patrocínio da Prefeitura, e é sempre solar, exuberante e colorido, apostando em imagens dos pontos turísticos como Cristo Redentor, Baia de Guanabara e Pão de Açúcar. O centro é mirado de cima, distante. Aparece limpo, sem poeiras e contrastes, trajando prédios novos e inovadores, além dos antigos e repletos de história. Essas memórias enquadradas no filme, apesar de reais, não contemplam as vivências e recordações que outros grupos têm do Rio. Por isso, surgem produtos como o "Olympia", rememorando um Rio cinza, cheio de pó e asfalto inacabado, obras abandonadas ou em andamento. A cidade é colorida e solar também, só que olhada das regiões centrais, longe das paisagens dos cartões-postais, trazendo os corpos desajustados, atléticos ou despreocupados de seus transeuntes.

\section{Rio, eu te amo}

O "Rio, eu te amo" é um filme dividido em dez curtas, feitos por onze cineastas: quatro são brasileiros e os outros são estrangeiros. Temos, então, um filme pensado por pessoas que vivem a realidade do Rio e do Brasil, e por pessoas que entendem essa realidade de fora, por um olhar estrangeiro. Os curtas "Pas de deux", "La fortuna", "O milagre", “Texas" e "Quando não há mais amor" não entraram na análise, pois tiveram ambientes internos como plano de fundo e/ou as histórias não envolviam a cidade. Assim, a nossa análise foi dividida em cinco partes, de acordo com os curtas-metragens analisados "Dona Fulana", "A musa", “Acho que estou apaixonado", "O vampiro do Rio" e "Inútil Paisagem".

"Dona fulana" de Andrucha Waddington é o primeiro curta a começar. Uma moradora de rua é acordada pelo porteiro de um prédio, ele joga um balde d'água fria nela. Logo depois desse ato, começamos a perceber que um homem a observa. Após a atitude pouco gentil do porteiro, aparecem catadores de lixo, engraxates e pessoas em situação de rua no Centro do 
Rio. Os pobres e a cidade aparecem de forma higienizada, as ruas são limpas, assim como as roupas, as peles e os cabelos dos personagens. Chama a atenção o fato de a personagem principal ser branca, interpretada pela atriz Fernanda Montenegro, o que pode não corresponder à realidade.

A velha moradora de rua aparece novamente escovando os dentes no chafariz, mas logo é interrompida por um policial, interrompendo seu ritual diário de higiene. O agente de segurança é grosseiro, diz que ela não pode usar àquela água. Então, a senhora o responde; ele tenta prendê-la. Depois de iniciada essa pequena confusão, o homem que observava de longe empurra o guarda no chafariz e corre com a senhora. Durante o diálogo dos dois, notamos que ele é seu neto.

O neto pergunta à avó o porquê de viver na rua já que ela tem casa e uma boa aposentadoria. A moradora de rua responde que gosta da rua, de gente, da cidade. Ela nessa situação porque quer. Conta que não precisa de casa, família, dinheiro, pois a cidade oferece de graça tudo o que é necessário para viver. E o neto prontamente a questiona: então, por que você não toma banho? Imediatamente o filme parece responder a essa indagação com uma cena dos dois na Cachoeira das Almas, na Floresta da Tijuca. Eles tomam banho juntos, estão felizes brincando com a água. Essa cena reforça a representação de uma cidade encantadora e boa de se viver, mesmo com seus problemas. Matos (2016) explica que as experiências estéticas dos festivais de cinema, e consequentemente dos filmes em geral, produzem sentidos sobre o mundo social. No caso do Rio, principalmente em um período de megaeventos, essas produções fílmicas contribuíram para uma representação específica da cidade, onde seus atributos apareceram como mercadorias a serem vendidas e consumidas. "Dona Fulana" é um exemplo de curta que reforça (e até mesmo constrói) os atributos positivos da capital fluminense.

Nos primeiros minutos do filme, a cidade é mostrada de cima, não sendo possível enxergar suas contradições e desigualdades. Porém, no decorrer da trama, Waddington vai descortinando uma miséria que de fato existe ao retratar moradores de rua, catadores de latinhas e os meninos engraxates, bem como a agressividade do policial e do porteiro mostrando que os cariocas nem sempre são amáveis e acolhedores. Embora esses temas tenham sido retratados de forma superficial, eles ainda são extremamente significativos porque descontroem a ideia de uma metrópole encantadora.

O segundo curta ("Musa" de Fernando Meirelles e César Charlone) começa mostrando a região central de cima na seguinte ordem: Central do Brasil, Teleférico, Morro da Providência. Um homem entra num trem no subúrbio, ainda de madrugada, em sentido às 
áreas nobres da Zona Sul do Rio de Janeiro. Até chegar à estação de trem, ele passa por prostitutas em um caminho pouco iluminado. Chega cedo ao bairro de Copacabana, ansioso para construir seus castelos de areia - é comum encontrar esculturas de areia nas praias do Rio, especialmente nesse bairro específico.

A Zona Sul do filme, diferente do subúrbio, é iluminada, colorida e solar. As pessoas vivem tranquilas, em harmonia, se cumprimentando diariamente com um sorriso. Para mostrar que Copacabana é frequentado por pessoas de origens diferentes, o filme exibe por dois minutos as pessoas que circulam na orla de pedras portuguesas: vendedor de Matte, jovem jogando bola, homem de terno, guardas em treinamento, homem correndo, mulher de salto alto, pessoas de bicicleta ou caminhando. Tais imagens remetem a ideia de bairro plural, um clichê que é reforçado com o som de berimbau e samba que toca ao fundo.

O escultor avista uma mulher, ele parece estar apaixonado por ela. Essa personagem não tem rosto, a câmera foca apenas em seus pés. O escultor corre para encontrá-la, mas não consegue alcançá-la, pois, as calçadas estão cheias de pessoas que querem curtir a praia, consumir os produtos dos quiosques, tirar uma fotografia. Não aceitando o fracasso inicial, ele tenta novamente. E quando finalmente chega perto da moça, ela encontra e beija outro homem. Revoltado, o escultor destrói seus castelos de areia. Ele dorme na praia e, no dia seguinte, enquanto o sol nasce, ele esculpe os pés da mulher e vai embora.

Neste curta-metragem, notamos um Rio turístico, com imagens de Copacabana, e o Rio não explorado pelo turismo, com imagens do subúrbio. Apesar do subúrbio também ser um lugar culturalmente rico, isso não é mostrado no filme. Só aparecem cenas de prostitutas num lugar pouco iluminado. Percebemos, então, uma possível indispensabilidade em ter apenas a Zona Sul como plano de fundo das histórias.

Cenas da feira da Glória e imagens aéreas do Cristo Redentor são exibidas antes do "Acho que estou apaixonado" de Stephan Elliot. Nesse curta, um taxista carioca está encarregado de receber um ator estrangeiro. $\mathrm{O}$ taxista fala muito, e o ator não gosta de falar. $\mathrm{O}$ motorista quer conversar, por isso acha o ator chato e mal-humorado. Ao avistar o Pão de Açúcar, o gringo fica encantado. Quando sai do carro, lemos I Love Rio no vidro traseiro. O estrangeiro fica tão fascinado com a paisagem que resolve escalar aquela montanha, mesmo sem ter equipamento de segurança. O motorista o segue. Em um momento da escalada, o ator quase cai e o motorista salva-o. Os dois se olham e o taxista o chama de parceiro. Para Pimentel (2014), este filme tem a função de promover uma ideia específica de hospitalidade, destino turístico e cultura. Focando na ideia de uma suposta receptividade por parte dos cariocas, o autor explica que se trata de uma construção para atrair cada vez mais visitantes e 
lucros. O filme, para Pimentel, seleciona formas de viver, gestos hospitaleiros e paisagens belas à propaganda que estava sendo construída à época, esquecendo sistematicamente as favelas, os negros e os espaços pouco atraentes aos turistas.

Quando eles conseguem concluir a escalada, no topo tem uma mulher vestida de branco, como um espírito. Ela canta: "É que eu preciso dizer que eu te amo; te ganhar ou perder sem enganos. Eu preciso dizer que te amo tanto...". Ela para de cantar, os beija na boca e voa pela cidade, até sumir na paisagem. $\mathrm{O}$ ator diz que o Rio de Janeiro (na verdade, é a Zona Sul) é mágico e que está apaixonado. A produção de Elliot repete o clichê do carioca bem-humorado e receptivo, bem como o do gringo mal-humorado. $\mathrm{O}$ estrangeiro muda o humor, pois está num Rio que se ama, em uma cidade mágica.

Mais cenas da Central do Brasil, e então começa "Um vampiro do Rio" de Im Sang Soo. Um garçom está ao lado da uma mesa, com mulheres negras e homens estrangeiros. Elas seriam prostitutas e eles seriam os clientes. Os homens dizem que o passaporte brasileiro é o mais barato do mercado negro, as prostitutas dizem que é porque aqui tem mulheres de todos os tons de pele. $\mathrm{O}$ garçom encontra uma amiga, uma prostituta, e a leva a um piquenique no parque. Eles se beijam, fazem sexo, ainda no parque, e ele a morde como um vampiro. Ele sai do parque e logo está na favela. As pessoas saem dos becos e começam a sambar, todos são vampiros. Quando o sol começa a aparecer, ele dispersa o samba. O curta de Im Sang Soo é o único que tem a favela como plano de fundo, por isso consideramos que esse espaço tão evidente na paisagem da cidade é apagado pelos diretores do produto. Segundo Pimentel (2014), esse espaço popular é representado pelo olhar estrangeiro de um coreano, por isso as ruas são completamente limpas, desertas, com poucos ruídos, diferente da forma que os brasileiros conhecem.

São exibidas cenas noturnas do Rio, e logo depois começa o curta "Inútil paisagem" de José Padilha. Um homem amanhece na pista de pouso de asa delta em São Conrado, Zona Sul da capital fluminense. Ele voa, passando pela maioria dos pontos turísticos: Cristo Redentor, enseada de Botafogo, aterro do Flamengo, Maracanã. Indo da Zona Sul à Zona Norte, o voador começa a dizer que o Rio de Janeiro é uma mentira, expressando suas experiências pessoais e os problemas que a cidade o impõe: lá embaixo, na cidade, não tem amor, a polícia mata, chove e inunda tudo, todo mundo morre, as crianças não têm escola por causa da violência. De cima é melhor, continua explicando, parece realmente que a cidade é maravilhosa. No final, o personagem fala que vai embora e, ironicamente, deseja uma boa Olimpíada a todos.

Em sua produção cinematográfica, Padilha mostra os contrastes do Rio Olímpico. 
Vista de cima, a cidade é bela, o que agradaria a muitos turistas. Teoricamente, diante daquela paisagem encantadora seria quase impossível refletir sobre os conflitos que ocorrem lá embaixo. No entanto, as falas do personagem vão quebrando essa ideia ao expor as contradições da cidade. A paisagem, nesse caso, não alienaria o pensamento crítico da persona. Voando, o homem esclarece que o Rio se prepara para receber os Jogos Olímpicos, mas não tem amor, educação, saúde e segurança. Apesar das transformações, o carioca continua sofrendo com seus problemas endêmicos.

Neiva (2014) lembra que a Arquidiocese local é proprietária dos direitos do Cristo e, por isso, não autorizou o uso das imagens, acreditando que a película continha cenas ofensivas à sua crença. Inicialmente, a Conspiração Filmes decidiu excluir esse curta, mas a instituição católica resolveu voltar atrás na sua decisão temendo uma repercussão midiática ainda mais desfavorável.

Se o projeto inicial do Cities of Love tinha a intenção de ressaltar as memórias positivas da cidade a fim de vendê-la como uma mercadoria, parece que o produto de Padilha é o único que apresenta ao público algumas memórias contrárias à ideia de cidade que naturalmente se ama. Neiva coaduna com este pensamento, ao dizer que independente de um desfecho feliz ou provocativo, o curta de Padilha é uma importante contraposição a essa narrativa harmônica (e hegemônica) sobre o Rio.

\section{Olympia}

Este filme começa contando a história de uma cidade rodeada por montanhas e florestas que se chamava Olympia. Seus habitantes eram os Voadores (ou os Alados) e os Pés no Chão. Os Alados eram como os humanos, só que mais ágeis pela capacidade de voar. Por outro lado, os Pés no Chão estavam presos à terra, e, por essa razão, se organizaram em poderes, partidos e instituições. Incapazes de saírem do solo, reconhecendo essa limitação, viram nos muros, nos exércitos e nas normas uma possibilidade de segurança.

Os Pés no Chão queriam os Voadores na terra para cumprirem suas leis. A rivalidade entre os dois grupos aumentou tanto que aconteceu a lendária Batalha do Sol, onde a maioria dos Alados foi capturada e morta. Alguns conseguiram fugir para as montanhas mais altas, preservando suas asas. Então, o grande tribunal decidiu, por lei, que todos os Alados sobreviventes teriam suas asas cortadas. Para assegurar de vez a ordem, decidiram que todos os recém-nascidos voadores seriam mutilados. Logo, a pena foi banida, transformada em ameaça e crime. Como uma forma de resistência, os rebeldes que fugiram para os montes 
durante a batalha, conservando suas habilidades, se encontravam à noite para voar, mas sempre baixo, longe da vigilância do sistema.

Um dia, uma menina chamada Democracia teve sua pena roubada pelo vento que entrava pela janela do banheiro. A pena cruzou a cidade e caiu na frente da catedral, o principal templo da ordem. Informada pelo "sacerdo-papa", a população identificou a Voadora e exigiu a sua condenação. A jovem foi julgada na praça, na frente de todos os cidadãos, e resolveu entregar sua cabeça ao invés de suas asas. O tempo passou, até que a imagem da jovem decapitada virou a marca do progresso. O controle e a ordem foram restaurados. No entanto, a humanidade nunca mais pôde voar.

No filme, Olympia é uma cidade com autoridades corruptas que vai ser sede da Olimpíada. Num clima de transformação do espaço urbano para receber o megaevento, o advogado Jean Carlos busca ajuda para denunciar crimes ambientais. O cineasta Rodrigo Mac Niven e a pesquisadora Lia ajudam o advogado na produção de um documentário. Nesse produto audiovisual, os três revelam as ilegalidades das obras da prefeitura da cidade de Olympia. Todos os três têm uma marca nas costas, como se suas asas tivessem sido cortadas. Essa é a parte de ficção.

"Olympia", o filme, também é um documentário. Ele apresenta depoimentos de especialistas e vítimas reais do processo de remoções da Vila Autódromo. Sobre a Vila Autódromo: quando o Rio de Janeiro foi escolhido para sediar os Jogos Olímpicos, em 2016, o plano da Prefeitura era demolir o antigo autódromo de Jacarepaguá (Zona Oeste) para construir o Parque Olímpico - estrutura para abrigar os atletas durante o evento. O projeto tinha a intenção de realizar obras no entorno e remover completamente a Vila, uma comunidade com moradores que já tinham sido removidos em uma outra época.

É dito que os moradores da comunidade, junto com técnicos da Universidade Federal Fluminense (UFF) e da Universidade Federal do Rio de Janeiro (UFRJ), criaram um Plano Popular de Urbanização como uma alternativa ao plano do governo municipal, para a Vila não ser removida (LACERDA, SENDRA, CARVALHIDO, 2019). Nada adiantou. Existia pouco diálogo entre a prefeitura e a população atingida pelas obras. Em "Olympia", os entrevistados disseram que a remoção da Vila Autódromo seria interessante para as empreiteiras, pois poderiam construir prédios residenciais para a classe média. O espaço revitalizado não seria utilizado por todas as pessoas que viviam nele antes, mas por novos moradores, por aqueles que podiam pagar mais.

"Olympia” dá mais destaque ao centro da cidade. Aparecem cenas da Central do Brasil, do Píer Mauá, da Cidade Nova e das barcas de Niterói com seus trabalhadores. A Zona 
Sul também é mostrada, mas não tanto quanto a região central. As obras não acabadas são exibidas, enquanto uma voz em off explica que elas tiveram um alto custo, diz que o metrô não chega até a Barra da Tijuca, como foi prometido, e as escolas estão ocupadas por alunos que desejam mais investimentos na educação.

Na cidade de Olympia, Democracia está no lugar do Cristo Redentor. A cidade é colorida, solar, também é cinza, tem prédios, obras e poeiras, revelando claramente uma construção da paisagem - ou uma reconstrução das paisagens difundidas incansavelmente pelas mídias e pela publicidade. Para Gauziski (2019), a paisagem é cultural antes de ser natural. As representações da natureza não são espontâneas e independentes dos seres humanos, pelo contrário: os ambientes são constantemente explorados e modificados pelo homem. Mesmo aqueles cenários que parecem obras espetaculares da natureza, como as montanhas, as florestas, as areias das praias cariocas e os campos floridos, é provável que o ser humano tenha exercido algum tipo de interferência neles, seja desviando o curso das águas, cortando árvores ou aterrando. A autora conclui que a paisagem é entendida como autênticas e independentes das ações humanas porque ao longo da história as convenções e técnicas pictóricas foram se tornando invisíveis aos olhos, impossíveis de serem mensuradas.

O produto diz que a sede já tem problemas financeiros, mas seus dirigentes não querem que a população saiba. Conta que Olympia está sendo vendida às empreiteiras e ao mercado internacional para ter visibilidade e obter mais dinheiro. No Rio de Janeiro, o vicegovernador, Francisco Dornelles, decretou estado de calamidade pública em 17 de julho de 2016, poucos dias antes do início da Olimpíada. O prazo deveria terminar em 2017, mas se estendeu. Endividado, o Rio ficou sem condições de pagar os salários e os fornecedores. Estado de calamidade pública é um termo definido por um decreto de 2010, editado pelo então presidente Luiz Inácio Lula da Silva. Esse decreto estabelece que a Defesa Civil Nacional e o Ministério da Integração Nacional são responsáveis por prestar socorro a estados e municípios vítimas de desastres. Desastre, nesse caso, se refere a eventos adversos, naturais ou produzidos, que causam danos a humanos, materiais e ambientes. Esse decreto pode ser usado quando o desastre é grande demais para o estado e o município resolverem sozinhos.

Reluzente, espetacular, monumental, maravilhosa. De acordo com Freitas (2011), essas características foram associadas ao Rio de Janeiro pelos governos e pela grande mídia antes e durante a programação dos megaeventos. $\mathrm{O}$ autor esclarece que entre os corpos vibrantes, as imagens lúdicas, os conflitos e as competições de todas as ordens, a relação entre cidade, comunicação e memória estavam ainda mais articuladas. Se a mídia tradicional representou o Rio como uma metrópole em desenvolvimento, produtos como "Olympia" 
trouxeram imagens silenciadas, como a remoção da Vila Autódromo, as violações aos direitos humanos e as dívidas adquiridas com as obras de revitalização.

\section{Considerações finais}

Esse trabalho se propôs a identificar e analisar como o Rio de Janeiro, sede de megaeventos esportivos, foi representado no cinema. Por isso, foi analisado um filme apoiado pela Prefeitura do Rio de Janeiro, "Rio, eu te amo", e um filme feito e pensado por artistasativistas, "Olympia". Essas diferentes representações não são vistas como mais importantes ou verdadeiras, pois ambas revelam as formas como esses diferentes criadores, de acordo com seus interesses, enxergaram esse momento da cidade.

O filme "Rio, eu te amo" ressalta as características tidas como positivas: é uma cidade solar, colorida, com belas paisagens, apaixonante. O carioca é representado como alegre, simpático e amigo. Por outro lado, com menos destaque, também são mostradas as características que podem ser negativas: aparecem cenas com prostitutas, menores abandonados, mendigos e vendedores ambulantes. E os moradores do Rio nem sempre são receptivos, também podem ser desrespeitosos.

O filme "Olympia" mostra mais cenas do centro da cidade, longe dos pontos turísticos da Zona Sul. Os bairros nobres são apresentados, mas não tanto quanto os da região central. O Rio é colorido, solar, mas também é cinza, tem prédios sujos, obras inacabadas e poeiras. $\mathrm{Na}$ parte de ficção, esse produto foca nos problemas financeiros da sede, na corrupção e na falta de diálogo entre os representantes políticos e a população. Na parte documental, ele aborda o tema da gentrificação, trazendo as falas de especialistas e vítimas do processo de remoções da Vila Autódromo.

Os dois filmes têm semelhanças e diferenças. Ambos exibem características positivas e negativas do Rio de Janeiro. O “Olympia” dá mais visibilidade aos problemas, enquanto o "Rio, eu te amo" expõe às características positivas da cidade. Acredita-se que apesar deste estudo analisar apenas dois filmes, já é possível ter uma ideia das representações que foram criadas sobre a cidade do Rio de Janeiro no período dos megaeventos. Novos comunicadores e formas de comunicar surgiram nesse cenário urbano, e outros tantos surgirão, acrescentando novas visões a essa discussão e possibilitando outras pesquisas.

\section{Referências}

FORTUNA, Vania. "Rio do porto maravilha", Rio de sentidos: lutas simbólicas por um 
consenso discursivo de cidade global. 2016. 207 f. Tese (Doutorado em comunicação) Faculdade de Comunicação Social, Universidade Federal Fluminense, Niterói, 2016.

GOTARDO, Ana. Rio para gringo: a construção de sentidos sobre o carioca e a cidade para consumo turístico. 2016. 164 f. Dissertação (Mestrado em Comunicação) - Programa de Pósgraduação em Comunicação, Universidade do Estado do Rio de Janeiro, Rio de Janeiro, 2016.

FREITAS, Ricardo. Da cidade-espetáculo à cidade-mercadoria: a comunicação urbana e a construção da marca RIO. Revista Eco-Pós, v. 12, n. 3, p. 49-65, jan. 2017. ISSN: 2175-8689. Disponível em: https://revistas.ufrj.br/index.php/eco_pos/issue/view/923. Acesso em: $15 / 07 / 2018$.

. Rio de Janeiro, lugar de eventos: das exposições do início do século XX aos megaeventos contemporâneos. In: Associação Nacional dos Programas de Pós-Graduação em Comunicação, 20., 2011, Porto Alegre. Anais de congresso. Porto Alegre: COMPÓS, 2011.

JAGUARIBE, Beatriz. Imaginando a cidade maravilhosa: modernidade, espetáculo e espaços urbanos. Revista Famecos, v. 18, n. 02, p. 327-347, jul. 2011. ISSN: 1415-0549. Disponível em: http://revistaseletronicas.pucrs.br/ojs/index.php/revistafamecos/issue/view/528. Acesso em: 17/06/2018.

MENDONÇA, Kleber. A "pacificação" dos sentidos: mídia e violência na cidade em disputa. Rio de Janeiro, RJ: Editora Caravanas, 2018.

POLLAK, Michel. Memória, esquecimento, silêncio. Revista Estudos Históricos, Rio de Janeiro, v. 2, n. 3, pp. 03-15, jan-jun, 1989.

RICOEUR, Paul. Tempo e narrativa. Campinas, SP: Papirus, 1994. . A memória, a história, o esquecimento. Campinas - SP: Editora Unicamp, 2007.

SÁNCHEZ, Fernanda. A reinvenção das cidades para um mercado mundial. Chapecó: Argos, 2003.

MORAES, Maria Teresa. A cidade do Rio de Janeiro nas vinhetas do Festival do Rio. In: Congresso Brasileiro de Ciências da Comunicação, 39., 2016, São Paulo. Anais de congresso. São Paulo: INTERCOM, 2016.

PIMENTEL, Luana. A hospitalidade no cinema: estudo sobre o filme Rio, eu te amo. 2014. 70 f. Trabalho de conclusão de curso (Curso superior de Hotelaria) - Faculdade de Turismo e Hotelaria, Universidade Federal Fluminense, Niterói, 2014.

NEIVA, Gabriel. A paixão de uma cidade: compreendendo as ramificações midiáticas do projeto "Rio, eu te amo". In.: Congresso Brasileiro de Ciências da Comunicação, 37., 2014, Foz do Iguaçu. Anais de congresso. Foz do Iguaçu: INTERCOM, 2014.

GAUZISKI, Débora. A paisagem olímpica do Rio de Janeiro: natureza e ruínas no discurso institucional. Revista Interin, v. 24, n. 1, p. 82-99, jan. 2019. ISSN: 1980-5276. Disponível em: https://seer.utp.br/index.php/i/issue/view/120. Acesso em: 18/02/2019. 
HALBWACHS, Maurice. A memória coletiva. São Paulo: Centauro, 2003.

LACERDA, Igor; SENDRA, Cláudia; CARVALHIDO, Guilherme. Estudo comparativo entre o discurso da mídia e do povo sobre a copa de 2014. Revista Alabastro, v. 1, n. 9, p. 104-116, dez. 2016. ISSN: 2318-3179. Disponível em: revistaalabastro.fespsp.org.br/index.php/ alabastro/issue/view/7. Acesso em: 21/05/2018 